\title{
'n Prakties-teologiese besinning oor die versteuring van die luisteraksie deur persepsies en die rol van preekgesprekke as dialogisering
}

\author{
Author: \\ Ferdi P. Kruger ${ }^{1}$ \\ Affiliation: \\ ${ }^{1}$ School of Ecclesiastical \\ Studies, North-West \\ University, South Africa \\ Correspondence to: \\ Ferdi Kruger \\ Email: \\ ferdikruger4@gmail.com \\ Postal address: \\ PO Box 75973, Lynwoodrif \\ 0040, South Africa \\ Dates: \\ Received: 10 Apr. 2012 \\ Accepted: 07 Aug. 2012 \\ Published: 30 July 2013 \\ How to cite this article: \\ Kruger, F.P., 2013, "n \\ Prakties-teologiese besinning \\ oor die versteuring van \\ die luisteraksie deur \\ persepsies en die rol \\ van preekgesprekke as \\ dialogisering', In die Skriflig/ \\ In Luce Verbi 47(1), Art. \#541, \\ 11 pages. $\mathrm{http} / / / \mathrm{dx} /$ doi.org/ \\ 10.4102/ids.v47i1.541 \\ Copyright: \\ (C) 2013. The Authors. \\ Licensee: AOSIS \\ OpenJournals. This work \\ is licensed under the \\ Creative Commons \\ Attribution License. \\ Read online:

Uit die kerklike praksis blyk dat prediking wat dikwels goed bedoel word en op biddende wyse gelewer word, voor die hindernis van persepsies stuit wat dan verlammend op die luisteraksie inwerk. Tussen die blote hoor van en 'n diepgaande luister na die prediking bestaan 'n groot verskil. In die lig hiervan word die volgende navorsingsvraag vir hierdie navorsing geformuleer: In hoe 'n mate begelei predikers hulle hoorders op 'n dialogiserende manier in die kuns om werklik te kan luister, sodat dít wat gesê en bedoel is die hoorders se persepsies kan beïnvloed? Ten einde hierdie navorsingsvraag te beantwoord, word die probleemveld vanuit verskillende prakties-teologiese invalshoeke verken. Metateoretiese perspektiewe vanuit die veld van die Sosiale Psigologie en Kommunikasiekunde word ook gebruik om daardeur insig oor die vorming van en die selektiewe aard van persepsies te verkry. In die ondersoek na normatiewe gesigspunte word die dialogiserende prediking en argumentasie vanuit Handelinge 17 en 19 verken. Die navorser kom tot die konklusie dat persepsies oor die prediker en die prediking verlammend kan inwerk en selfs daartoe aanleiding kan gee dat hoorders die kerk verlaat. Verder is ook bevind dat dialoog voor die preeklewering, die dialogiese gerigtheid van die prediking as deel van die liturgie van die gemeente, asook die preekgesprekke na afloop van die prediking, daartoe kan meewerk dat verkeerde persepsies reggestel word. Hierdeur word die gemeente 'n pratende gemeenskap wat van diepgaande kommunikasie leef.

A practical-theological reflection on the role of perceptions in the act of listening and the importance of dialogue in discourses about sermons. From the ecclesiastical praxis it seems that preaching faces hindrances caused by negative perceptions, regardless of the good intentions of preachers and the interdependence between prayer and preaching. There is a vast difference between hearing sermons and listening to sermons. In the light of this problematic praxis, the following research question has been formulated: To what extent do preachers equip their listeners in a dialogue situation to listen profoundly with the object to influence the perceptions of listeners about the preacher and the preaching? In order to address this research question, the problem is investigated by taking into account the present practical theological vantage points concerning this field. This research field is further explored by trying to get a grasp on metatheoretical perspectives from the fields of Social Psychology and Communication Sciences. The author tries to investigate the difficult process of forming perceptions as well as the selective nature of perceptions. In an investigation into normative vantage points, perspectives from Acts 17 and 19 are explored with regard to the role of dialogue in Paul's preaching. The researcher comes to the conclusion that negative perceptions are indeed endangering the ecclesiastical praxis and can even cause listeners to leave the church. Preachers should utilise dialogue in preparing their sermons; focusing on the dialogic nature of preaching in the context of the liturgy. In addition, preachers should endeavour to stimulate feedback after delivering of their sermons in order to rectify fallacious perceptions. Congregations should become communities nurtured by profound communication.

\section{Inleiding}

De Klerk (1998:79) neem kerklike kommunikasie op kritiese wyse in oënskou en bemerk tekortkomings in die stimulasie van kommunikasie tussen die mens en God. Hy onderstreep die krisis in kerklike kommunikasie wat eredienste wil opvrolik (opdirk), saam-eet-en-drinkbyeenkomste, kampe en sosiale aksies meebring en wat as genoegsame kommunikasie beskou word (De Klerk 1998:80). Joubert (2009:37) bevind dat die groeiende negatiewe persepsies oor die kerk en die Christendom een van die hoofoorsake van dalende en krimpende lidmaatgetalle in Suid-Afrika is. Joubert (2009:37) verwys na 'n studie waarin bevind is dat tot soveel as 70\% van die lidmate tussen die ouderdom van 18 en 23 die kerk verlaat en dat $36 \%$ van hierdie lidmate teen 
die ouderdom van 30 nog nie na die kerk teruggekeer het nie. Hierdie lidmate se persepsies teenoor die kerk en sy lidmate is dikwels negatief, maar daar bestaan tog tekens dat daar 'n herwaardering vir die boodskap van die Bybel bestaan (Joubert 2009:36). Hieruit word afgelei dat die kerk met 'n kommunikasie-dilemma te make het. Troeger (2007:80) en Müller (2009:22-23) verwoord hierdie dilemma en toon aan dat die predikers wat die Woord moet verkondig, net soos die hoorders, oorloop van persepsies en verwagtings. Nel (2003:34-36) beskryf die persepsie wat meermale by die hoorders bestaan, naamlik dat die kerk 'n 'house of pain' [plek van marteling] is. Die persepsie bestaan meermale by die hoorders dat die predikers die prediking misbruik om hulle eie sienings aan die hoorders op te dis en daardeur manipulerend met die prediking te werk gaan (Nel 2003:54).

In die prakties-teologiese navorsing is al meermale oor die hermeneutiek van die hoorder en oor die prediking as kommunikasiegebeure besin (Hermelink 2007:33; Cilliers 2004:9; Pieterse 1990:97; Robinson 2004:203; Vos 1996:154; Dingemans 1991:137). Pieterse (2001:23) benadruk byvoorbeeld die feit dat die kerk 'n kommunikatiewe gemeenskap is wat op grond van goeie kommunikasie bestaan. As kommunikatiewe gemeenskap kom die hoorders immers minstens elke week saam om binne die ruimte van die erediens na preke te luister (Pieterse 2010:23; vgl. ook Dingemans 1991:11). Meuser (1983:112-113) verduidelik die erns van kommunikasie onder die erediens en toon op grond van 'n uitspraak van Luther aan dat God se Woord nooit van sy mense geskei kan word nie.

In onlangse navorsing oor die wyse waarop die hoorders na boodskappe luister, het die volgende insiggewende feite na vore gekom:

- Die hoorders spandeer ongeveer $42 \%$ - $60 \%$ van hulle tyd aan die handeling van luister (Steinberg 2011:68).

- Joubert (2009:20-21) verduidelik dat die luisterproses kompleks is en toon verder aan dat die hoorders in ' $n$ tyd van informasie-oorbelading leef. Die vraag onstaan na wie hulle moet luister en na wie nie.

- In die navorsing is bevind dat die gemiddelde luistereffektiwiteit van hoorders slegs $25 \%$ is (Tubbs \& Moss 2008:37-38). Die implikasie hiervan is dat bykans $75 \%$ van die boodskappe nie gehoor word nie.

- Cleary (2010:76-77) toon vanuit 'n hoorderskonteks aan dat die hoorders vier maal vinniger kan dink as wat die sprekers kan praat. Dit gebeur dus dat die hoorders ook aan ander dinge dink terwyl die sprekers besig is om te kommunikeer.

- Steinberg (2011:68) asook Cleary (2010:77) stel dat die vanselfsprekendheid om te kan hoor, in plaas daarvan om luister as 'n vaardigheid aan te leer, 'n vername oorsaak vir die swak luistertoedrag van sake is.

Predikers ontkom nie aan hierdie situasie nie en opper meermale die versugting dat die hoorders nie luister na dit wat hulle met moeite kommunikeer nie (Cleary 2010:76). Joubert (2009:29) verwoord die versugting van die kerk in 'n post-Christelike kutuur as 'n dilemma waar die invloed van die kerklike stem boonop toenemend verdwyn. Kerklike kommunikasie word voorts bemoeilik deur die feit dat gevoelsgedrewe kennis en die kennis van die logika dikwels met mekaar bots en dat die kennis van die logika in die Westerse wêreld telkens die oorhand kry (Joubert 2009:57). Stott (1999:74) sluit hierby aan deur die aandag daarop te vestig dat die kerk deur kommunikatiewe prediking baie het om te bied en juis ' $n$ vername rol moet speel wanneer omstandighede in die samelewing donker word.

In hierdie artikel word gefokus op 'n moontlike rede waarom die prediking dikwels nie die gewenste uitwerking het nie. Die klem word ook geplaas op die gebrekkige dialogiese wisselwerking tussen die prediker en die hoorders in die preekmaakproses asook in die preeklewering. Immink (2003:261) het vantevore daarvoor gepleit dat kommunikasie gedurende die prediking diepgaande van aard moet wees. Die kommunikasie gedurende die prediking word egter deur heelwat aspekte gekonfronteer wat kommunikasiestoornisse kan veroorsaak(Eswine2004:1; Pieterse1991:18;Vos 1996:155). Kommunikasiestoornis is enigiets wat daartoe aanleiding kan gee dat die boodskap van die prediking nie reg begryp word nie (Bang 2004:131). Hierdie artikel stel ondersoek in na die mate waarin persepsies oor die prediker en die prediking daartoe aanleiding kan gee dat 'n kommunikasiestoornis intree. 'n Verdere oogmerk van hierdie artikel is om aan te toon dat dialoog en gereelde terugvoer optimaal benut moet word om verkeerde persepsies by die hoorders reg te stel. Verkeerde persepsies is dikwels destruktief vir die handeling van luister en die prediking en juis daarom is dit belangrik om oor hierdie ondersoekveld te besin. In hierdie artikel word aansluiting gevind by die metodologiese lyne vir 'n reflektiewe balans wat Osmer (2010:3) vir die praktiesteologiese navorsing onderskei het. Osmer (2010:3) het in sy besinning oor ' $n$ hermeneutiese spiraal binne ' $n$ praktiesteologiese ondersoek die volgende vier hooflyne onderskei:

- 'n Beskrywend-empiriese ondersoek waarin die navorser inligting versamel om die probleemveld binne die praksis beter te begryp.

- 'n Interpretatiewe ondersoek waardeur die navorser poog om te analiseer waarom sekere handelings binne die probleemveld geskied.

- 'n Normatiewe ondersoek waarin normatiewe vrae vanuit ander velde van die Teologie gestel word.

- 'n Pragmatiese ondersoek waarin die navorser poog om perspektiewe daar te stel om die problematiese praksis te herstel.

Die ondersoek geskied in vier fases. Fase een bied 'n beskrywende refleksie rondom die probleemveld in die Praktiese Teologie. In fase twee word op interpretatiewe wyse vanuit die Sosiale Psigologie en die veld van die Kommunikasiekunde 'n verkennende ondersoek gedoen oor die problematiek hoedat persepsies 'n invloed op die handeling van luister kan uitoefen. 'n Intradissiplinêre gesprek word met hierdie velde gevoer. In die derde fase kom 'n normatiewe ondersoek aan die beurt en basisteoretiese perspektiewe vanuit Handelinge word ontgin. In die vierde fase word sodanige praktykteoretiese perspektiewe ontgin 
wat moontlik daartoe kan lei dat predikers met groter ywer die hoorders sal begelei in dialoogvoering. Hierdeur word gepoog om die gaping tussen persepsies oor die prediking en die prediker aan die een kant en die realiteit of werklikheid aan die ander kant, te verklein.

\section{'n Beskrywende verkenning van die probleemveld met verwysing na voorbeelde van navorsing op hierdie terrein}

Heyns en Pieterse (1990:58) toon aan dat die dialoog in die handeling van die prediking geskied, selfs al is die prediker alleen aan die woord. Op elke uitlating van die prediker word assosiasies uit die hoorder se eie ervaring opgeroep en sekere beelde kom na vore (Heyns \& Pieterse 1990:58). Firet (1987:261) benadruk weer dat die rol van verhoudings in die kerk op 'n interaksie-situasie gefokus moet wees. Deur sy werk het Firet die noodsaak daarvan dat prediking dialogies van aard moet wees, opnuut op die agenda van die Praktiese Teologie geplaas.

\section{Navorsing wat die dialogiese aard van die prediking beskryf}

Die afgelope ses jaar het sekere outeurs oor die dialogiese aard van die prediking besin:

- Cilliers (2010:93) toon aan dat die prediking ten doel het om 'n ander raamwerk om die hoorders se lewens te plaas. Dit bring mee dat die predikers vertroud moet wees met die tyds- en lewensomstandighede van die hoorders. Dit is van wesenlike belang dat die predikers met die hoorders in verbinding tree onder die kommunikasie van die prediking.

- Erasmus (2007:199) benadruk dat die wese van die prediking dialogies van aard moet wees. Indien prediking nie dialogies van aard is nie, is dit nie kommunikasie nie. Die hoorders moet daarom in die prediking betrek word deur hulle te laat dink, te laat antwoord en te laat argumenteer.

\section{Navorsing wat die wederkerigheid in die preekmaakproses benadruk}

Sommige outeurs het in hulle navorsing die klem op die noodsaaklikheid van wederkerigheid in die preekmaakproses laat val:

- Stark (2005:78) beklemtoon die feit dat die prediking van meet af aan op die deelname van die hoorders gerig moet wees asook op hulle verbintenis ten opsigte van die handeling van die prediking.

- McClure (1995:7-8) pleit vir medewerkende prediking wat die hoorders bemagtig om in die prediking ook hulle eie stem te herken wat sodoende dan 'n fokuspunt in die gemeente word.

\section{Navorsing wat die rol van die preekgesprek benadruk}

In die navorsing is ook aangetoon dat die preekgesprek belangrik is:
- Cilliers (1996:129) meen dat 'n preekgesprek, ook genoem 'n ekklesiale diskoers, daartoe aanleiding gee dat geloofsimpressie in geloofsekspressie oorgaan. Deur die proses van preekgesprekke verryk die prediker en die gemeente mekaar en dien die preek as inhoud en fasilitering van die gesprek. Sodoende dra die preekgesprekke daartoe by dat die predikers in die preekmaakproses nie vereensaam nie. So word die swygsaamheid van die gemeente en die eensaamheid van die prediker deurbreek.

- Lange (1987:134) toon op grondige wyse aan dat die relevansie van preke deur die hoorders ervaar word, of nie. Hulle gee dus uitsluitsel oor die relevansie van preke.

\section{Navorsing wat die rol van gesindhede en persepsies benadruk}

Die probleemveld wat geïdentifiseer is en wat oor die destruktiewe rol van negatiewe persepsies handel, is meermale in die navorsing vermeld sonder om dieper daarop in te gaan:

- Van der Meulen (2008:159) benadruk die feit dat die predikers stoornisse of blokkasies in hulle eie gemoedere asook moontlike blokkasies in die gemoedere van die hoorders in ag moet neem. Hy waarsku egter dat misverstande eie aan kommunikasie is en dat hierdie misverstande dikwels verkeerde persepsies laat ontstaan (Van der Meulen 2008:149).

- Olyott (1998:42-43) toon aan dat prediking wat nie toegespits is nie ('pointed preaching'), geen aanspraak op die naam prediking het nie. Hy toon verder aan dat die prediker moeite moet doen om die hoorders in die preekmaakproses te betrek. Die prediker moet homself inspan om die hoorders se moontlike daaglikse belewenisse en dit wat daartoe aanleiding kan gee dat hulle gesindhede en hulle persepsies nadelig beïnvloed word, te verreken.

Uit bogenoemde navorsingseleksie oor die probleemveld blyk dit dat grondige navorsing reeds gedoen is om die prediking as kommunikasiegebeure asook die rol van die hoorder hierin, te benadruk. Dit is egter noodsaaklik om die rol van persepsies in die luisterproses nader te omlyn.

\section{'n Interpretatiewe verkenning van die problematiek rondom persepsies in die luisterhandeling na preke}

Omdat die Praktiese Teologie op die optrede van mense in die konkrete samelewingsverbande fokus, vind oorvleueling plaas met die ondersoekterrein van ander wetenskappe wat op die menslike gedrag fokus (Heyns \& Pieterse, 1990:14-15). In die Sosiale Psigologie asook die Kommunikasiekunde is alreeds verskeie kere indringend ondersoek gedoen hoedat persepsies gevorm word en hoedanig dit interpersoonlike kommunikasie beïnvloed (Cleary 2010:76; Grant \& Borcherds 2009:47-48; Woolfolk 2007:251; Bergh \& Theron 2006:116; Steinberg 2011:67 asook Weiten 1992:124). Hierdie artikel 
wil graag erkenning gee aan die intradissiplinêre benadering ten opsigte van die aangrensende sosiale wetenskappe (Cartledge 2003:15).

\section{Metateoretiese perspektiewe vanuit die Sosiale Psigologie Persepsievorming}

Weiten (1992:108) definieer persepsie as 'n proses waardeur seleksie, organisasie en interpretasie van sensoriese inligting geskied. Persepsievorming het te make met 'n proses waardeur sensoriese inligting vertaal of georganiseer word sodat betekenis geheg word aan dit wat rondom die waarnemer gebeur (Gass \& Seiter 2003:102; Smit \& De J. Cronje 1999:366; Louw \& Edwards 1998:149 asook Baron \& Byrne 1994:265). Woolfolk (2007:251) verduidelik die impak van persepsies en toon verder aan dat persepsies een van die determinante in die sensoriese geheue van mense is. Hierdeur word bepaal wat in die werkende geheue behou sal word vir verdere gebruik. Alhoewel die sensoriese geheue van die mens die vermoë het om baie inligting te kan absorbeer, bestaan die moontlikheid dat sekere inligting binne een tot drie sekondes kan verdwyn. Volgens Wood en Wood (1999:89-99) geskied die persepsuele rangskikking ooreenkomstig 'n neiging by die hoorders om inligting aan die hand van vier beginsels te groepeer:

- Ooreenstemming: Mense plaas inligting in dieselfde groepe en wil dit wat bymekaar hoort, bymekaar plaas.

- Nabyheid en verwantskap: Hiervolgens neig persone om dinge wat aan mekaar verwant is, in verhouding tot mekaar te plaas.

- Kontinuiteit: Indien inligting neig om 'n kontinue lyn te vorm, neig mense om dit met mekaar te verbind.

- Afsluiting: Mense het die neiging om dit wat hulle waarneem wat nie 'n voltooide beeld vertoon nie, te voltooi om sodoende afsluiting te bereik.

\section{Persepsies is selektief en persoonlik van aard}

Persepsies skep dikwels 'n probleem in interpersoonlike verhoudings, juis omdat dit 'n selektiewe proses is (Bergh \& Theron 2006:116). Hierdie individuele en selektiewe proses van persepsies oefen volgens Bergh \& Theron (2006:116) 'n invloed uit op heelwat aspekte van 'n persoon se lewe soos werkverrigting, sosiale interaksie asook gesindheidsvorming. Volgens Bergh en Theron (2006:124) kan 'n verskeidenheid faktore persepsies beïnvloed en selfs vorm.

- Die waarnemer: Subjektiewe faktore neig om waarnemers van stimuli te beïnvloed. In hierdie opsig is gesindhede, motiewe, belange, vooroordele, voorkeure, vorige ervarings en verwagtings die lense waardeur waarnemers dinge of mense waarneem. Subjektiewe persepsies kan verander word, veral indien sosiale en kulturele omstandighede verander.

- Die voorwerp wat waargeneem word: Die unieke eienskappe van dit wat waargeneem word, beïnvloed persepsies. In hierdie opsig speel faktore soos beweging, klank, aantreklikheid, skoonheid en grootte 'n vername rol. Persoonlike hoedanighede en die bydrae wat persone lewer, word dikwels direk beïnvloed deur die agtergrond waarteen voorwerpe of mense waargeneem word.

- Die situasie: Menslike gedrag word in konteks geïnterpreteer. Die tydstip, werksomstandighede en sosiale milieu van die konteks waarbinne mense waargeneem word, is dus bepalend vir die vorming van persepsies.

\section{Persepsies as basis vir sosiale interaksie}

In interpersoonlike verhoudings en kommunikasie is mense gebonde aan persepsies wat gevorm word (Weiten 1992:123). Alhoewel hierdie persepsies subjektief en selektief van aard is, is dit noodsaaklik, aangesien dit die basis van verdere sosiale aksie vorm (Bergh \& Theron 2006:125). Die aanvanklike indrukke wat oor persone gevorm word, vorm die basis waarvolgens toekomstige inligting verwerk en georganiseer word (Louw \& Edwards 1998:146). Persepsies wat oor persone gevorm word, is volgens Bergh en Theron (2006:125) meer kompleks as gevolg van die volgende drie redes:

- Wanneer indrukke van persone gevorm word, is mense dikwels aangewese op die waarneming van eienskappe wat nie altyd met die blote oog waargeneem word nie.

- In die waarneming van menslike gedrag word intensies en bedoelings van mense waargeneem of hierdie bedoelings word dikwels op grond van iemand se gedrag veronderstel.

- Die gevaar bestaan altyd dat kommunikators doelbewus probeer om ander se indrukke te manipuleer deur iets voor te gee wat nie werklik is nie.

Op grond van bogenoemde drie redes toon Bergh en Theron (2006:125) asook Smit en De J. Cronje (1999:367) aan dat iemand se persepsie oor persone dikwels verkeerd is vanweë valshede en vooroordele wat daarin vervat is. Mense is egter voortdurend besig om opinies van ander persone se optrede te vorm. Waarnemers neig om in die vorming van indrukke kortpaaie te wil kies (Bergh \& Theron 2006:125 asook Smit \& De J. Cronje 1999:368). Die volgende kortpaaie word volgens Bergh and Theron (2006:128) in die vorming van indrukke gevolg:

- Waarnemers is geneig om mense in skemas te kategoriseer. Met skemas word 'n veralgemening ten opsigte van sake of persone bedoel.

- Die neiging bestaan om aan sekere dinge en persone op grond van waarneming voorrang te gee. Faktore soos spraaksaamheid, vriendelikheid en geslag speel met die eerste oogopslag 'n belangrike rol.

- Negatiewe vooroordele neig om persone se persepsies sterker te beïnvloed as die geval met positiewe vooroordele.

- Fisiese skoonheid en aantreklikheid beïnvloed die vorming van persepsies op 'n direkte wyse.

- Mense verkeer maklik onder die indruk dat persone oor sekere eienskappe beskik net omdat hulle aan 'n sekere groep behoort. Die probleem met hierdie stereotipering is dat die unieke eienskappe van individue geïgnoreer word.

- 'n Enkele eienskap van 'n persoon word as maatstaf geneem om ' $n$ algemene opinie te vorm. Iemand wat vlot 
praat, word dikwels as intelligent beskou, sonder om ander aspekte soos sosiale aanpasbaarheid in aanmerking te neem. Hierdeur ontstaan die gevaar van onderskatting of oorskatting van persone.

- Persone neig om ander mense nie in eie reg te beoordeel nie. Mense beoordeel ander op grond van soortgelyke persone wat reeds ontmoet is en wat deel van hulle verwysingsraamwerk is.

- Projeksie van persone se eie persoonlikheid bring dikwels mee dat ander mense se eiesoortige eienskappe nie waardeer word nie. Die innerlike gevoelens speel dikwels 'n oorheersende rol.

- In-die-groep- en buite-die-groep-beoordeling vind plaas. Mense binne die groep word bevoordeel ten koste van diegene wat buite die groep is.

- Selektiewe persepsie is wanneer mense dit wat waargeneem word, as 't ware spoedlees. Hierdeur word negatiewe verwagtings en indrukke verkeerdelik gestimuleer.

\section{Metateoretiese perspektiewe vanuit die Kommunikasiekunde}

Effektiewe luister is belangrik in die kommunikasieproses (Steinberg 2011:67; Du Plooy-Cilliers \& Olivier 2000:33; Cleary 2010:75 asook Huebsch 1995:45).

\section{Omskrywing van 'n persepsie}

Barker en Angelopulo (2010:270) omskryf persepsies vanuit die fokusarea van die Kommunikasiekunde as die proses waartydens die hoorders inligting deur middel van hulle sintuie ontvang en betekenis hieraan koppel. Ellis en McClintock (1994:1) beskryf persepsies as inligting wat deur die sintuie waargeneem word, deur die brein geprosesseer word, in die geheue gestoor word, maar wat ook 'n fisiese of verstandelike reaksie voortbring.

\section{Persepsies en verwysingsraamwerke}

Steinberg (2011:67) toon aan dat luister een van die persepsuele prosesse is. Mense beskik oor vyf sintuie waardeur hulle inligting ontvang en waarneem, naamlik gesig, gehoor, tas, reuk en smaak. Deur inligting wat deur die sintuie waargeneem word, probeer mense sin maak uit die gebeure rondom hulle (Du Plooy-Cilliers \& Olivier 2000:36). Waarneming van stimuli geskied deur die mens se verwysingsraamwerk as 'n stel interafhanklike feite, idees, waardes, oortuigings en gesindhede (Wilson et al. 1989:63). Hierdie verwysingsraamwerk vorm die basis waarop mense gebeurtenisse en sake begryp en dit vorm ook die filter vir die vorming van persepsies (Steinberg 2011:69). Plug et al. (1988:386) dui aan dat hierdie oordeel, gegrond op die verwysingsraamwerk, rigtinggewend is vir mense se gedagtes en gedrag.

Steinberg (2011:69-70) toon aan dat die vorming van persepsies 'n persoonlike proses in elke mens se lewe is. Alhoewel persepsies met waarneming te make het, is dit geen waarborg dat dit 'n akkurate evaluasie van die ware stand van sake is nie (Barker \& Angelopulo 2010:271). Persepsies as ' $\mathrm{n}$ aspek van 'n persoonlike verwysingsraamwerk is ongelukkig dikwels misvormd en verwronge en toon min ooreenkoms met die werklikheid (Grant \& Borcherds 2009:3).

\section{Fases van persepsievorming}

Volgens Steinberg (2011:70) asook Grant en Borcherds (2009:48) word persepsies in drie fases gevorm:

- Seleksie: Daar is baie sensoriese stimuli rondom mense, maar slegs dit wat hulle aandag trek en relevant is, word geselekteer. Twee faktore gee hiertoe aanleiding, naamlik selektiewe blootstelling en selektiewe aandag. Slegs daardie inligting wat ' $\mathrm{n}$ bevestiging is van ' $\mathrm{n}$ persoon se verwysingsraamwerk word dus geselekteer. In die kommunikasieproses gebeur presies dieselfde deurdat persone hulleself vir sekere stimuli oopstel, maar ander stimuli blokkeer. Dit gee daartoe aanleiding dat verkeerde persepsies gevorm word. Selektiewe aandag bring mee dat hoorders hoor en sien wat hulle graag wil hoor en sien.

- Organisasie: In hierdie fase word die relevante inligting in betekenisvolle patrone georganiseer. Dit is die proses van persepsuele organisasie. Mense neig om 'n geheelbeeld van sake en persone te vorm.

- Interpretasie: In hierdie fase word waarde en betekenis gekoppel aan dit wat geselekteer en georganiseer is. Juis omdat hierdie proses 'n persoonlike saak is, gebeur dit dat mense se evaluasie van dinge en persone van mekaar kan verskil.

Du Plooy-Cilliers en Olivier (2000:38) asook Barker en Angelopulo (2010:272) besin daaroor om die akkuraatheid van persepsies te verbeter. Die volgende metodes word voorgestel:

- 'n Multisensoriese vasstelling van feite moet plaasvind. Persepsies rus dikwels op inligting wat deur die een sintuig waargeneem is. Deur meer sintuie te gebruik, kan die geldigheid en akkuraatheid van persepsies verbeter word.

- Die metode van konsensus is ook belangrik. Hierdie metode hou in dat persoonlike persepsies met ander mense se interpretasies vergelyk moet word. Sodoende word die ontbrekende inligting in 'n persoon se eie persepsie aangevul en 'n verwronge persepsie reggestel.

\section{Die verskil tussen hoor en luister}

Daar bestaan ' $n$ algemene konsensus in die Kommunikasiekunde dat die vermoë om te luister een van die mees prominente prosesse in die kommunikasieproses is (vgl. Steinberg 2011:75; Cleary 2010:77; Grant \& Borcherds 2009:49 asook Du Plooy-Cilliers \& Olivier 2000:43). Indien klanke gehoor word, moet dit op'n aktiewe wyse geprosesseer word. Dit bring mee dat die ontvanger van 'n boodskap moet onthou wat die inhoud van die kommunikasie is en dat die boodskap ook 'n gepaste respons vereis (Steinberg 2011:75). Daar bestaan, aldus Cleary (2010:78-79), verskillende vlakke van luister:

- Om te hoor is die proses waartydens klankgolwe ontvang word. 
- Deur aandag te gee, fokus die hoorder op dit wat gesê is en op die wyse waarop dit gesê is. Slegs 'n paar van hierdie stimuli word deur die brein geselekteer.

- Die proses waartydens inligting geanaliseer en geïnterpreteer word, loop uit op begrip. Hierdie luistervlak is van kardinale belang, aangesien dit die wyse waarop die hoorder reageer, beïnvloed. Begrip is van kardinale belang in die proses van aktiewe luister.

- Om te onthou, is die proses waartydens die boodskap gestoor word om later weer opgeroep te word.

- Die finale stap is wanneer die hoorder reageer op dit wat die boodskapper oorgedra het. Die reaksie vertolk die begrip en gevoel van die luisteraar of die hoorder. In hierdie fase is dit noodsaaklik om sekere sake te verduidelik of verder te verhelder.

Die luistervlakke word volgens Steinberg (2011:78-79) selfs ingewikkelder indien gelet word op die verskillende maniere waarop die hoorders na boodskappe luister:

- Luister met die oog daarop om dit te geniet.

- Luister met die oog daarop om verskillende soorte inligting te bekom. Verskillende mense luister daarom ook met verskillende verwagtings daarna.

- Sekere hoorders luister krities en is daarop ingestel om die inhoud van die boodskap te bevraagteken.

- Reflektiewe luisteraars is sensitief vir wedersydse begrip vir mekaar se sienings en boodskappe en is ook op terugvoer ingestel.

\section{Die noodsaaklikheid van terugvoer}

Goeie kommunikasie vereis dat die gespreksgenote aan mekaar terugvoer sal gee ten opsigte van wat gehoor is (Steinberg 2011:83; Cleary 2010:83). Met die terugvoer word vasgestel of die boodskap op die regte wyse verstaan is en of die kommunikasiestyl van albei deelnemers dalk verander moet word (Barker \& Angelopulo 2010:207). Terugvoer word egter belemmer indien die hoorders nie met aandag luister nie. Dan word onvoldoende terugvoer gegee wat effektiewe kommunikasie in die wiele ry (Steinberg 2011:84). Cleary (2010:83-85) onderskei die volgende tipes terugvoer wat gegee kan word:

- Irrelevante response.

- Response wat onderbreek word sodat die kommunikators daardeur nie toegelaat word om hulle gesprek te voltooi nie.

- Sommige response beland op 'n syspoor en dwaal van die onderwerp af. Hierdie tipe respons is ' $n$ aanduiding daarvan dat daar nie werklik na die kommunikator geluister word nie.

- Deur ontoeganklike response weier hoorders om erkenning te gee aan die feit dat daar met hulle gekommunikeer word. Hierdeur word die selfbeeld van die kommunikator skade berokken.

Steinberg (2011:84) beskou die volgende aspekte as onontbeerlik vir effektiewe terugvoer in interpersoonlike kommunikasie:

- Fokus op wat gesien en gehoor is en waak teen eensydige gevolgtrekkings op grond van dit wat ander persone pas gesê of gedoen het.
- Die hoorders moet daarop ingestel wees om meer beskrywend as veroordelend te wees. Konstruktiewe en opbouende kritiek stel kommunikators en die hoorders in staat om 'n postiewe verandering in hulle gedrag na vore te bring.

- Onmiddellike of spoedige terugvoer is meer akkuraat en spesifiek as terugvoer wat op 'n later stadium gelewer word. Selfs negatiewe gevoelens word makliker bespreek indien dit onmiddellik by wyse van terugvoer geskied. Negatiewe gevoelens neig om oor 'n langer tyd buite verhouding te ontwikkel. Terugvoer wat onsmaaklik is, moet egter nie onmiddellik geuiter word nie.

- Daar is ook beperkings aan die terugvoer. Die basiese reëls van kommunikasie, naamlik om ander die geleentheid te gee om ook te praat, moet eerbiedig word. Beperkte terugvoer is egter nie sinoniem met 'n gebrek aan terugvoer nie.

\section{Basisteoretiese perspektiewe op kommunikasie en dialoog in Handelinge 17 en 19}

Die kerk het haar onstaan te danke aan die verkondiging van die Woord. Die voortbestaan van die kerk is dus ook afhanklik van volharding in die prediking van die Woord van God (Ridderbos 1985:483). Floor (1979:5) toon die uniekheid van die prediking aan deur daarop te wys dat die God van die Bybel by uitstek die God van kommunikasie is en dat die Bybel, as die Woord van die God, by uitnemendheid die boek van goddelike kommunikasie is. Blaiklock (2002:650) toon aan dat die inhoud van Handelinge die verandering beskryf wat die verspreiding van God se Woord oor die wêreld meegebring het. De Villiers (1985:218) sluit hierby aan en toon aan dat Handelinge beskryf hoe Christus se volgelinge, onder leiding van die Heilige Gees, die boodskap van verlossing tot in Rome uitgedra het. Binne die raamwerk van die ondersoekveld van hierdie artikel is dit noodsaaklik om daarop te let dat die verkondiging van die Woord, soos Handelinge dit vermeld, soms mooi vrug opgelewer het, maar ook telkens te staan gekom het voor persepsies wat as stoornisse ervaar is soos kwaadsprekery, onwilligheid om te luister en opstande (Floor 1979:9). Handelinge bevat die sentrale openbaring oor die transformasie wat die verkondiging van die Woord oor Jesus Christus voortgebring het. In hierdie onderafdeling word daar dus van naderby ondersoek ingestel na dit wat Handelinge 17 en 19 openbaar ten opsigte van die rol van dialoog in die kommunikasie van die prediking.

\section{Basisteoretiese perspektiewe op Woordverkondigingsbegrippe in Handelinge}

Floor (1979:6) toon aan dat veral die volgende vier begrippe vir prediking in die boek Handelinge gebruik word, naamlik:

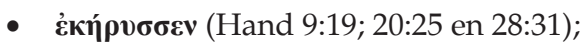

- $\quad \boldsymbol{\varepsilon} \boldsymbol{v} \boldsymbol{\alpha} \gamma \boldsymbol{\gamma} \boldsymbol{\varepsilon} \mathbf{\imath} \zeta \mathbf{0} \boldsymbol{\mu} \boldsymbol{\varepsilon} \boldsymbol{\theta} \boldsymbol{\alpha}$ (Hand 13:32; 14:7; 15:16; 16:10 en 17:18);

- $\quad \boldsymbol{\kappa} \alpha \tau \eta ́ \gamma \gamma \varepsilon \lambda \lambda \boldsymbol{o v}$ (Hand 13:5, 38; 15:36; 16:17, 21; 17:3, 13);

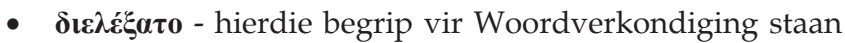


sentraal in Handelinge en kom slegs drie maal elders in die Nuwe Testament voor, naamlik in Matteus 9:34, Hebreërs 12:5 en Judas vers 9. In Handelinge word hierdie begrip 10 maal gebruik (Hand 17:2, 17; 18:4, 19; 19:8, 9; 20:7, 9 asook 24:1 en 25).

\section{Basisteoretiese perspektiewe op Handelinge 17:1-3, 10-15 asook 19:8-9}

\section{Basisteoretiese perspektiewe op Handelinge 17:1-3}

In Handelinge 17 word die optrede van Paulus in Tessalonika, Berea en Atene beskryf (Blaiklock 2002:129). Handelinge 17:2 en 3 vermeld dat Paulus met die Jode uit die Skrifte gedialogiseer het, wat die betekenisnuanse van redeneer

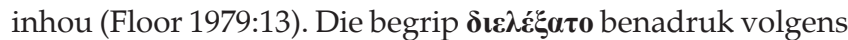
Floor (1979:14) dat Paulus se dialogisering nie daarop gemik was om saam met sy hoorders na die waarheid te soek nie, maar wel om deur sy redenasie en dialoog met hulle, die waarheid uit te dra. Floor (1979:14) spreek die hipotese uit dat die betoogtrant van vraag en antwoord nie in hierdie tipe prediking van Paulus uitgesluit kan word nie. Dit is dus nie onmoontlik dat vrae voor, tydens en selfs na die prediking aan die apostel gevra is nie. Hierop sou hy telkens vanuit die Skrifte geantwoord het (Floor 1979:15).

In Handelinge het $\boldsymbol{\delta} \mathbf{1} \boldsymbol{\varepsilon} \boldsymbol{\lambda} \mathbf{\varepsilon} \xi \boldsymbol{\alpha} \mathbf{c} \mathbf{0}$ nie bloot die betekenis van praat of spreek nie, maar ook die betekenis van bespreking, gedagtewisseling en dispuut (Floor 1979:8). In die begrip

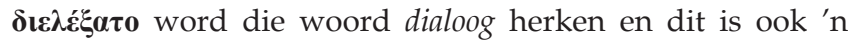
aanduiding van 'n gesprek in 'n meer formele omgewing soos 'n toespraak (Louw \& Nida 1993, 1:392). Hierdie begrip kan ook daarop dui om te argumenteer of om in 'n dispuut betrokke te raak (Louw \& Nida 1993, 1:439). Bromiley (1985:422-423) is van opinie dat hierdie begrip in die Nuwe Testament selfs die betekenisnuanse van bespreek, oordink, bepeins en besinning het. Volgens Brown (1986:551) kan hierdie begrip ook beskou word as ' $n$ tegniese term en selfs ' $n$ kwalifiseringsmetode vir Paulus se onderrig in die sinagoges wat dikwels daartoe aanleiding gegee het dat hy die Woord op eiesoortige wyse verkondig het.

Osborne (1995:245) sluit by bogenoemde gedagtes aan, naamlik dat die prediking op oorredende wyse tot die hoorders gerig was deur vanuit die gesagvolle teks van die Skrifte met die hoorders te redeneer. Deur hierdie dialogiserende en beredenerende prediking wou Paulus sy hoorders oorreed (Osborne 1995:246). Die dialogiserende gedagte word in Handelinge 17:3 met twee deelwoorde

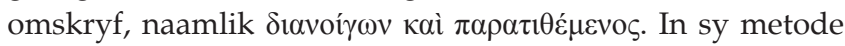
van dialogiserende Woordverkondiging het Paulus twee

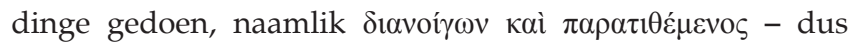
die Skrifte oopgemaak en die Skrifte langs mekaar gelê (Larkin 2006:400). Volgens Osborne (1995:246) beteken die begrippe ook dat Paulus aan die hoorders verduidelik het en dit gelytydig uit die Skrifte bewys het. Larkin (2006:538) toon aan dat Paulus juis hierdie metode van dialogiserende prediking gebruik het, omdat hy bewus was van die stoornisse en hindernisse wat op sy prediking sou wag. Hy het daarom met logika te werk gegaan. Volgens Osborne (1995:245) gebruik Paulus in Handelinge 17:3a vir sy hoofargument die logika dat Christus moes ly en uit die dood opstaan. Sy tweede argument word in Handelinge 17:3b aangetref, naamlik verkondig ek aan julle. Vanuit hierdie twee stellings maak hy die konklusie dat hierdie Jesus die Christus is. In sy dialogiserende prediking wissel Paulus die redenasietrant af met die metode van getuig oor en bekend maak van wat

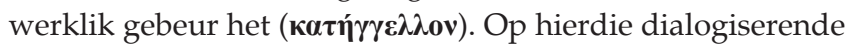
prediking van Paulus het uiteenlopende reaksies ontstaan. Sommige mense het oortuig geraak en Paulus gevolg, terwyl andere met die persepsie van afgunstigheid, moeilikheid veroorsaak het (Larkin 2006:338).

\section{Basisteoretiese perspektiewe op Handelinge 17:10-15}

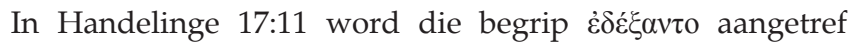
wat daarop dui dat die hoorders in Berea ontvankliker vir Woordverkondiging was (Larkin 2006:340). Volgens Larkin (2006:240) dui hierdie begrip aan dat die hoorders hier oop was vir die verkondiging; hulle was bereid om sonder vooroordele te luister en het 'n toleransie geopenbaar. Osborne (1995:249) lei af dat die hoorders in Berea bereid was om te luister, bereid was om te leer en ook bereid was om die verkondiging regverdig te beoordeel. Die mense in Berea het twee dinge volgens Osborne (1995:248) gedoen. As hoorders het hulle met belangstelling na die Woord geluister - die begrip $\pi \rho \circ \theta u \mu i \alpha \varsigma$ is hier opvallend. Die hoorders het die Skrif ook elke dag ondersoek ( $\alpha$ $\alpha \kappa \rho \imath v o v \tau \varepsilon \varsigma)$.

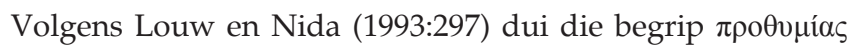
op 'n volhardende manier om gewillig te wees om iets te doen; 'n bereidwilligheid. Larkin (2006:340) bemerk hierin 'n gretigheid by die hoorders om die Woord te ontvang en in te neem wat gesê word. Daarom was by hierdie hoorders se luisteraksie sprake van entoesiasme (Larkin 2006:340). Hierdie gretigheid om meer te hoor en te luister, het saamgeval met 'n ondersoek en evaluering van dit wat Paulus verkondig het, om te bepaal of dit in ooreenstemming met die Skrifte self is (Osborne 1995:249). In Berea waar die persepsies van gelowiges gevorm is deur ' $n$ gretigheid om te luister en om na afloop van die verkondiging van die Woord die inhoud te toets, was daar groei (Green 1999:657).

\section{Basisteoretiese perspektiewe vanuit Handelinge 19:8 en 9}

Floor (1979:10) bemerk 'n ringskomposisie in Handelinge 19:8-9. Die ringskomposisie bestaan uit drie fokuspunte in elke vers, naamlik aksie, reaksie en weer aksie. Hierdie twee verse staan ook in kontras met mekaar deurdat vers 8 verduidelik hoedanig Paulus in die sinagoge in Efese opgetree het en hoe hy in die skool van Tyrannus te werk gegaan het (Larkin 2006:561). Blaiklock (2002:156) toon aan dat Paulus gedurig die samekomste van die Jode by die sinagoge opgesoek het. Vir drie maande het Paulus gedialogiseer met sy hoorders in die sinagoge oor die koninkryk van God en het hy daadwerklk probeer om hulle te oorreed. Larkin (2006:361) bemerk in hierdie dialogiserende prediking 'n gesindheid van om niks terug te hou vir die hoorders wanneer dit kom by die inhoud van die prediking aangaande die koninkryk van God nie. 
By diehoorders in die sinagoge was daar egter'n koppigheid van weiering om oortuig te word. Daar was 'n persepsie dat hulle net wou hoor wat hulle wil hoor (Blaiklock 2002:651). Paulus het hierna die gelowiges eenkant geneem en afsonderlik in die skool van Tyrannus besprekings gehou. Floor (1979:11) toon aan dat Paulus aan sy dissipels, naamlik gelowiges wat graag wil leer, onderrig gegee het. In Handelinge 19:8 dui die begrip redeneer op Paulus se preekmetode, maar in vers 9 dui dieselfde begrip weer op sy onderwysmetode (Floor 1979:11). In die skool van Tyrannus het Paulus sy onderwys in die vorm van 'n dialoog gelewer (Larkin 2006:261). Paulus het ook daar die sake van die koninkryk van God gedialogiseer (Floor 1979:12). Hierdie dialogiserende onderrig van Paulus het meegebring dat mense van oral in Asië die Woord van God gehoor het (Larkin 2006:261). Dit is opmerklik dat die verharding wat by die Jode in die sinagoge ingetree het op grond van die dialogiese prediking van Paulus nie moedeloosheid by die apostel teweeggebring het nie (Osborne 1995:275). Die persepsie van weiering om deur die apostel oortuig te word, het 'n ander deur geopen, naamlik om in die skool van Tyrannus onderrig te gee (Osborne 1995:275).

In die skool van Tyrannus is nie meer net op die Sabbat gedialogiseer nie, maar daagliks (Osborne 1995:275). Osborne (1995:276) bemerk selfs hierin 'n gesindheid van gewilligheid by Paulus as prediker sowel as by die hoorders om van die koninkryk van die hemel te praat en ook daarna te luister. Blaiklock (2002:650) toon aan dat alleen daar waar sodanige verbintenis ten opsigte van die prediking en die luister na die Woord bestaan, die reaksie van die Woord wat uitkring, bereik kan word. Groenewald (1986:491) toon op sy beurt aan dat Paulus se veranderde strategie om in die skool van Tyrannus onderrig te gee, gesien kan word as 'n meer noukeurig toegepaste dialogisering. Volgens Floor (1979:16) is dit kenmerkend van Paulus se dialogiserende prediking dat hy nie van allerlei dialoogtegnieke gebruik gemaak het in sy prediking nie. Die boodskap aangaande die koninkryk van die hemel het die inhoud gebly. Op hierdie wyse het Paulus aan dialoog die regte en gepaste plek gegee. Dit blyk dat Paulus ook sy prediking met intensiewe en diepgaande gesprekke in die skool van Tyrannus voortgesit het (Floor 1979:16). Op hierdie wyse kon Paulus na sy hoorders luister en hulle na hom (De Villiers 1985:231).

\section{Praktykteoretiese perspektiewe op die invloed wat persepsies op die luisterproses uitoefen}

In aansluiting by die metodologie wat Osmer (2010:3-7) vir prakties-teologiese navorsing onderskei, word in fase 4 van hierdie artikel gefokus op die formulering van perspektiewe - perspektiewe wat moontlik as oplossing kan dien ten opsigte van die probleem in die ondersoekveld. In hierdie fase van die artikel word daarop gefokus hoe praktiesteologiese navorsing op die perspektiewe in fase 1 tot 3 moet reageer. Die fokus val ook daarop hoe dit kan aanleiding gee dat die praksis gewysig moet word. Die navorsing word daarom gedoen teen die agtergrond daarvan dat die prediker van die Woord van God, soos alle ander mense, beperkte insig het oor die boodskap van die Bybel en ook 'n beperkte belewenis van die werklikheid van die hoorders het (Cilliers 1996:128). Die gemeente se samestelling verteenwoordig 'n versameling insigte en ervarings. Die gemeente as hoorders van preke kan dus die prediker help om nie net ander kante van die teks nie, maar ook ander kante van die werklikheid raak te sien (Kruger 1999:107).

\section{Praktykteoretiese perspektiewe op die persepsies van die hoorders}

Praktykteoretiese perspektiewe op die persepsies van die persoon van die prediker

Cilliers (1996:19) toon aan dat die prediker in die prediking 'n vername rol speel. Hy lig veral die volgende persepsies oor die prediker uit wat in die weg van kommunikasie staan:

- Predikers impliseer dat hulle presies weet wat die Here wil hê. Met hierdie houding word die inhoud van die prediking voorgehou as die enigste manier waarop geleef kan word. Op subtiele wyse word wegbeweeg van die waarheid dat die teks gesag het en dat die gesag nie by die persoon van die prediker berus nie. Die prediker plaas dus sy preek in God se mond.

- Grootheidswaan bedreig die predikers se prediking. Predikers trap maklik in die slaggat om die indruk by lidmate te skep dat hulle die enigste mense is wat in staat is om aan die eise van die teks te voldoen. Vanuit hulle voorbeeld wil die predikers lidmate oproep om dieselfde voorbeeld na te volg.

- Predikers begaan in die prediking ook tongglipse. Hulle trag om dit wat nie reg is nie met ander frases te vervang en reg te stel.

Firet (1987:305) beskryf persepsies wat oor die prediker bestaan meer omvattend en toon aan dat die manifestasie van die selfbeeld van die prediker dikwels direk aanleiding gee tot die vorming van persepsies. Die volgende persepsies kan ontstaan:

- Die skep van 'n persepsie dat die prediking impliseer dat die prediker God se regterhand is.

- Die skep van die persepsie dat die prediker hom as verlosser van die gemeente voordoen.

- Die skep van 'n persepsie dat die prediker oor die wysheid van Salomo beskik.

- Die persepsie ontstaan dat die prediker homself as God se luidspreker voordoen.

- Die prediker wat die persepsie laat ontstaan dat hy God se offer is wat homself gedurig vir ander mense moet offer en homself dus lewensvreugde moet ontsê.

- Die persepsie dat die prediker God se regter is wat namens Hom sekere oordele moet vel.

- Die ontstaan van 'n persepsie dat die prediker onaantasbaar is.

Vroeër in die artikel (vgl. 'Persepsievorming') is aangetoon dat hoorders volgens kontoere van vier sake persepies oor persone vorm, naamlik ooreenstemming, nabyheid of verwantskap, kontinuiiteit en afsluiting. Dit impliseer dat die 
hoorders dinge wat volgens hulle bymekaar hoort, bymekaar wil voeg om 'n eenheidslyn te vorm. Die hoorders vorm daarom opinies oor die predikers se optrede terwyl hulle preek, maar ook op grond van dit wat hulle waarneem. Alles wat die predikers doen, vorm stukke van die legkaart van persepsies. Hierdie persepsies oor die predikers is bepalend vir die wyse waarop die hoorders na die prediking gaan luister. Dit is juis belangrik dat daar in daardie stadium nadere inligting verskaf moet word. Dit is verder aangetoon (vgl. 'Persepsies as basis vir sosiale interaksie') dat alhoewel persepsies dikwels subjektief en selektief van aard is, dit wel noodsaaklik is vir die verdere sosiale aksie deur die hoorders.

Persepsies is noodsaaklik vir die wyse waarop die hoorders gaan deelneem. Die aanvanklike indrukke wat oor persone gevorm is, vorm die basis waarvolgens toekomstige inligting verwerk en georganiseer word. In die vorming van indrukke oor persone is die hoorders dikwels aangewese op die waarneming van eienskappe wat nie altyd met die blote oog waargeneem kan word nie. In die waarneming van die predikers se gedrag word intensies en bedoelings waargeneem. Hierdie besef bring nederigheid by die predikers, want selfs met die beste bedoelings is die hoorders voortdurend besig om persepsies oor die predikers te vorm. Hierdie intrinsieke neiging by die hoorders om persepsies oor die predikers te vorm, onderstreep die belangrikheid daarvan dat persepsievorming ook tot nut van die handeling van die prediking aangewend kan word (vgl. Adams 1986:25 asook De Klerk 1975:105). Wie predikers is en hoe hulle voor mense optree, praat ' $\mathrm{n}$ taal, selfs al word geen woorde gebruik nie (Nel 2000:130).

\section{Praktykteoretiese perspektiewe oor dialoog en prediking}

Die prediking geskied in die ruimte van dialoog en daarom is dit noodsaaklik dat daar koppeling tussen die prediker en die hoorders moet wees (Pieterse 1987:166; Stott 1982:69). Van der Meulen (2007:82-83) toon aan dat die prediking funksioneel moet wees om die hoorders in ontmoeting met God te bring. Die hoorders het immers die wens om met wat verkondig word, te kan identifiseer. Hulle verwag dat preke 'n ondersteunende en transformerende effek op hulle lewens sal uitoefen (Van der Meulen 2008:84). McClure (1995:20) beskou die gebrekkige van-aangesig-tot-aangesigkontak tussen die predikers en die hoorders as 'n diepgaande probleem. Formele en onpersoonlike verhoudings skep 'n kommunikasiestoornis en verhoog die vorming van onakkurate persepsies. Mcclure (1995:21-22) toon aan dat predikers maklik in die studeerkamer vereensaam en dat hulle die hoorders van hulle vervreem. Om van die hoorders te verwag om te reageer op dit wat hulle vir die eerste maal onder die erediens hoor, is menslik gesproke onmoontlik.

Mcclure (1995:23) pleit daarom daarvoor dat kerke gemeenskappe van die Woord sal wees waarin alle gelowiges op krities-opbouende wyse verantwoordelikheid vir die prediking neem om daardeur die realiteit na die prediking terug te bring. In die voorafgaande besinning, in fase 1-3 van hierdie artikel, is aangetoon dat die dialoog juis ook ten doel het om die afstand tussen persepsies en die realiteit te oorbrug. In fase 3 is gedokumenteer hoedat die prediker, Paulus, dialoog as metode aangewend het om juis die hoorders te begelei daar waar weerstand ingetree het. Hierdie gesprekvoering, waartydens hy ook met die hoorders geredeneer het oor die sake van die koninkryk van God, het vrug opgelewer.

Die prediking het immers ten doel om die hoorders te oorreed (Kruger 2002:234). Pieterse (2008:149) benadruk dat wederkerigheid of gesprek ten grondslag van die prediking lê. Hierdie wederkerigheid kom op niks anders as dialoog neer nie. Egte dialoog bring egte kommunikasie voort. Pieterse (2008:150) besin oor maniere waarop die dialogiese gehalte van preke verhoog kan word deur middel van 'n omvattende gesprek vooraf, tydens, asook na die preek. Hy doen die volgende aan die hand:

- 'n Preekwerkgroep (waarvan die samestelling gedurig moet verander) vergader vooraf saam met die prediker om oor die teks en die implikasies van die toepasing van die preek te besin. Hierdie groep help die prediker om sy insig oor die konteks van die hoorders te verbreed.

- Tydens die preek word die vrae, probleme en aktuele gebeure aan die orde gestel en vanuit die Woord belig.

- Na afloop van die prediking vergader die preekwerkgroep weer om oor die prediking en kommunikatiewe gehalte van die prediking te besin.

Mislukte kommunikasie vind dikwels plaas as gevolg van onakkurate persepsies (Tubbs \& Moss 2008:66). Hierdie persepsies is belangrik en is bepalend vir die tipe kommunikasie wat die hoorders met die predikers gaan hê en selfs of hulle hoegenaamd met hulle wil kommunikeer. Dialoog stel die predikers en die hoorders in staat om empatie met mekaar se persepsies te hê. Die dialogiese proses stel die predikers en die hoorders in staat om hulle in die posisie van ander persone in te dink wat deur die proses van empatie bereik word. Hoe meer akkuraat die persepsies is, hoe meer effektief geskied kommunikasie (Tubbs \& Moss 2008:66). De Wet (2006:644-645) pleit daarom vir 'n verdieping in die kommunikasie waartydens die predikers en die hoorders met verdiepte aandag na mekaar moet luister om sodoende die Woord nie in die lug te laat bly hang nie, maar te laat grondvat op die vlak waar die hoorders hulle bevind. Die konstruktiewe rol van die dialoog wat reeds vóór die preeklewering begin, kan baie nuttig wees om die Woord met chirurgiese presiesheid teen die regte invalshoek tot in die hart van die hoorders se lewens te laat insny (De Wet 2006:645).

McClure (1995:49) toon op grondige wyse die wese van die kerk aan as 'n pratende gemeenskap. In die pleitdooi wat hy rig vir 'n 'round-table'-benadering [tafelrondebenadering] ten opsigte van die prediking, benadruk hy die feit dat die prediking saam met ander maniere van gemeentebediening meer op gesprekvoering gefokus moet wees. Die prediking moet daarom 'n neerslag wees van hierdie voortdurende gesprek van die gemeente by wyse van 'n dinkskrum (McClure 1995:50). Alhoewel alle hoorders nie fisies betrokke 
kan wees by 'n vooraf-preekwerkgroep nie, moet die ruimte en geleentheid gebied word dat hierdie hoorders hulle insette tot die preekgesprek kan lewer. Op hierdie wyse word oorreding deur middel van interaksie bereik (McClure 1995:56). In fase 2 van hierdie artikel is aangetoon dat mense oor 'n verwysingsraamwerk beskik. Dialoog is die proses waardeur die hoorders in staat gestel word om die nodige verstellings aan hulle verwysingsraamwerke te maak. Kreatiewe liturgie waarbinne die prediking sy eiesoortige plek het, verdien natuurlik ook voortdurend die aandag van die prediker. Hierdeur word die kommunikatiewe gehalte van die hoorders se ontmoeting met God juis verhoog (Van der Leeuw \& Struijs 2007:145 \& De Klerk 2010:457-460). Clasen (2008:48-50) vestig die aandag op die liturgie as kommunikatiewe gebeurtenis. Die implikasie is dat meer sintuie van die hoorders ingespan moet word, aangesien dit ook die gevaar van verkeerde persepsies verminder. In fase 2 van hierdie artikel is aangetoon dat verwronge persepsies juis ontstaan as gevolg van die feit dat net een sintuig gebruik is. Cilliers (2008:92) pleit daarvoor dat die liturgie ook moet sin maak net soos die prediking. Die liturgie kan bydra om meer sintuie in te span om die hoorders sodoende te help om diepgaande te luister.

\section{Praktykteoretiese perspektiewe op preekgesprekke as terugvoer op die prediking en nie as terugvoer oor die prediker self nie}

Daar is al meermale in die Praktiese Teologie oor die rol van preekgesprekke en preekanalise besin (Cilliers 1996:128; Pieterse 2010:124-135). Hierdie artikel vind aansluiting by die grondige navorsing en moontlike modelle wat alreeds geïdentifiseer is en daarom sal nie weer opnuut na nog moontlike vorms van preekanalise gekyk word nie. In hierdie onderafdeling sal die klem eerder geplaas word op die vorming van die regte persepsie by die prediker ten opsigte van preekgesprekke. Pieterse (2008:150-151) toon aan dat preekgesprekke volwassenheid van die predikers vereis. Die predikers moet hulleself daarin oefen om vooraf en ook na afloop van die prediking ruim geleentheid aan alle hoorders te bied om aan die dialoog deel te neem. Van Leeuw en Struijs (2007:144) toon aan dat volwassenheid opgesluit lê in die regte persepsie van die predikers ten opsigte van die preekgesprek, naamlik dat die gesprekke preekbespreking behels en nie 'n gesprek oor die prediker self is nie.

Van Leeuw en Struijs (2007:146-148) toon verder aan dat die prediking ook 'n performatiewe karakter het. Hierdie karakter kom tot uiting in die wisselwerking waarin kommunikasie tussen die prediker, die teks en die gemeente plaasvind. In die preek moet die hoorders tot ' $n$ verbintenis kom en sodoende moet die preek weer gebore word deur deel van die polsende lewe van die hoorders te word (De Klerk 2010:462). Preekgesprekke moet dus daarop fokus om weer te gee dit wat onder die prediking gehoor is en die verandering wat ter sprake kom na aanleiding van dit wat gehoor is. Daar moet ook ruim geleentheid gebied word om 'n bespreking te voer oor moontlike misverstande en persepsies wat ontstaan het as gevolg van dit wat gehoor is. Van Leeuw en Struijs (2007:149) toon aan dat die hoorders as gevolg van hulle verwysingsraamwerk en die selektiewe aard van persepsievorming dikwels geneig is om dinge in 'n preek te hoor en af te lei wat glad nie deur die prediker bedoel of geuiter is nie.

Terugvoering op preke by wyse van preekgesprekke, vorm een van die vernaamste wyses waarop misverstande en verwronge persepsies geïdentifiseer en reggestel kan word (Van Leeuw \& Struijs 2007:150). Hierdeur kan kommunikasie wat moontlik ontspoor het, weer op koers gebring word en persepsievorming op 'n gesonde wyse bevorder word.

\section{Slot}

Die prediking staan sentraal in die opbou van die gemeente. Natuurlik bou prediking alleen nie die gemeente op nie, maar sonder die prediking gebeur dit ook nie. Predikers spandeer dikwels baie energie aan die voorbereiding van preke, maar ervaar dat die preke 'n beperkte effek het. Telkens stuit predikers voor hulle eie persepsies asook die persepsies wat lidmate oor die prediker en die prediking het. Om werklik te kan luister, is anders as om te kan hoor. Die rol van dialoog in die preekvoorbereiding, in die lewering van die preek en ook na afloop van die prediking moet as 'n belangrike hulpmiddel beskou word om verkeerde persepsies te help verander. Die persepsies van die hoorders is bepalend vir die wyse waarop na die prediking geluister en daarop gereageer word, asook vir die meelewing van die lidmate in die gemeente. 'n Dialogiserende gemeente is 'n pratende gemeente en die gemeente behoort in elke preek haar eie stem te kan herken.

\section{Erkenning Mededingende belange}

Die outeur verklaar dat hy geen finansiële of persoonlike verbintenis het met enige party wat hom nadelig kon beïnvloed in die skryf van hierdie artikel nie.

\section{Literatuurverwysings}

Adams, J.E., 1986, The biblical view of self-esteem, self-love and self-image, Harvest House, Oregon.

Bang, S.J., 2004, 'The form of the sermon and effective communication: A homiletical study', PhD thesis, Faculty of Theology, PU for CHE, Potchefstroom.

Barker, R. \& Angelopulo, G., 2010, Integrated organisational communication, Juta, Cape Town.

Baron, R.A. \& Byrne, D., 1994, Social psychology, Allyn \& Bacon, New York.

Bergh, Z. \& Theron, A., 2006, Psychology in the work context, Oxford University Press, Cape Town.

Blaiklock, E.M., 2002, 'A historian looks at the New Testament', in D. Alexander \& P. Alexander (eds.), The Lion handbook to the Bible, pp. 650-651, Lion Hudson, Oxford.

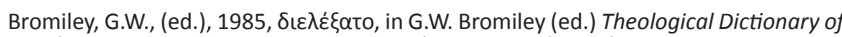
the New Testament, pp. 422-423, Eerdmans, Grand Rapids.

Brown, C., $1986 \delta$ ¿ $\varepsilon \lambda \varepsilon \dot{\varepsilon} \alpha$ to, in L. Coenen, E. Beyreuther \& H. Bietenhard (eds.), The New International Dictionary of the New Testament Theology, Vol. 3, pp. 551-553, Zondervan, Grand Rapids.

Cartledge, M.J., 2003, Practical theology - Charismatic and empirical perspectives, Paternoster, London.

Cilliers, J., 1996, Die uitwissing van God op die kansel: Ontstellende bevindinge oor Suid-Afrikaanse prediking, Lux Verbi, Kaapstad.

Cilliers, J., 2004, Die genade van gehoorsaamheid, Lux Verbi, Kaapstad.

Cilliers, J., 2008, 'Silence is golden: Liturgy beyond the edge of language' [Stilte is goud werd: Lituergie strek verder as taal], Praktiese Teologie in Suid-Afrika 23(1), 19-35. 
Cilliers, J., 2010, 'Preaching as reframing of perspective' [Prediking as herformulering van perspektiefl, In die Skriflig/In Luce Verbi 44(1), 86-98. http://dx.doi. van perspektief], In die
org/10.4102/ids.v44i1.138

Clasen, F.J., 2008, 'Liturgy on the edge of change' [Liturgie op die snykant van verandering], Praktiese Teologie in Suid-Afrika 23(1), 48-50.

Cleary, S., 2010, The communication handbook: A student guide to effective communication, Juta, Cape Town.

De Klerk, B.J., 2010, 'Die Heilige Gees en die prediking in die erediens', In die Skriflig/In Luce Verbi 44(2), 455-473. http://dx.doi.org/10.4102/ids.v44i2.155

De Klerk, W.J., 1998, Die vreemde God en sy mense, Human \& Rousseau, Kaapstad.

De Klerk, W.J., 1975, Pastorale sensitiwiteit, Perskor, Johannesburg.

De Villiers, J.L., 1985, 'Handelinge: Teologie', in A.B. du Toit (red.), Handleiding by die Nuwe Testament, Band 4, bl. 218-266, NG Kerkuitgewers, Pretoria.

De Wet, F.W., 2006, 'Die kommunikatiewe struktuur in eietydse gereformeerde prediking - Van liniêre na sirkulêre gang', In die Skriflig/In Luce Verbi 40(4), 617647. http://dx.doi.org/ 10.4102/ids.v40i4.362

Dingemans, G.D.J., 1991, Als hoorder onder de hoorders: Hermeneutische homiletiek, Kok, Kampen.

Du Plooy-Cilliers, F. \& Olivier, M., 2000, Let's talk about interpersonal communication, Heinemann, Sandton.

Ellis, R. \& McClintlock, A., 1994, If you take my meaning: Theory and practice in human communication, Edward Arnold, London.

Erasmus, J.A., 2007, 'Prediking en spiritualiteit: 'n Homiletiese studie oor die verband tussen prediking en geestelike groei', ThD-proefskrif, Fakulteit Teologie, Noordwes-Universiteit, Potchefstroom

Eswine, Z., 2004, 'Spiritual warfare and preaching: Toward a theology of "noise" for evangelical homiletics', viewed 8 February 2006, from http://ehomiletics.com

Firet, J., 1987, Het agogisch moment in het pastoraal optreden, Kok, Kampen.

Floor, L., 1979, 'In die skool van Tirannus: 'n Ondersoek na die plek van dialoog in teologiese onderrig en prediking', Rede gelewer tydens die promosieplegtigheid van die Teologiese Skool Potchefstroom, [Ongepubliseer].

Gass, R.H. \& Seiter, J.S., 2003, Persuasion, social influence and compliance gaining, Harper Collins, New York.

Grant, T. \& Borcherds, R., 2009, Communicating @work: Boosting your spoken, written and visual impact, Van Schaik, Pretoria.

Green, M., 1999, 'Good news from the first Christians', in D. Alexander \& P. Alexander (eds.), The Lion handbook to the Bible, pp. 655-656, Lion Hudson, Oxford.

Groenewald, E.P., 1986, Handboek bybelse geskiedenis, NG Kerk Boekhandel, Pretoria.

Hermelink, J., 2007, 'The theological understanding of preaching hope', in C. Vos, L.L. Hogan \& J.H. Cilliers (eds.), Preaching as a language of hope, pp. 29-58, Studia Homiletica, 6.

Heyns, L.M. \& Pieterse, H.J.C., 1990, Eerste treë in die Praktiese Teologie, Promedia, Pretoria.

Huebsch, J.C., 1995, Communication skills, Kagiso Tertiary, Pretoria.

Immink, F.G., 2003, In God geloven: Een praktisch-theologiese reconstructive, Meinema, Zoetermeer

Joubert, S., 2009, Jesus 'n radikale sprong, Christelike Uitgewersmaatskappy, Vereeniging.

Kruger, F.P., 1999, 'Prediker en preekgesindheid: 'n Prakties-teologiese studie in die lig van die pastorale briewe', ThM-verhandeling, Fakulteit Teologie, PU vir CHO, Potchefstroom.

Kruger, F.P., 2002, 'Prediking en gesindheidsverandering: 'n Prakties-teologiese studie in die lig van Hebreërs', ThD-proefskrif, Fakulteit Teologie, PU vir CHO, Potchefstroom.

Lange, E., 1987, Predigt als Beruf, Aufsätze zu Homiletik, Liturgie und Pfarramt, Chr. Kaiser, München.

Larkin, W.J., 2006, 'Acts', in P.W. Comfort (ed.), Tyndale cornerstone Biblical commentary, pp. 17-400, Tyndale House Publishers, Carol Stream.
Louw, D. \& Edwards, D., 1998, Sielkunde: 'n Inleiding vir studente in Suider-Afrika, Heinemann Voortgesette Onderwys, Sandton.

Louw, J.P. \& Nida, E.A., 1993, Greek English lexicon of the New Testament, Vol. 1, United Bible Studies, New York.

McClure, J.S., 1995, The roundtable pulpit, Abingdon, Nashville.

Nel, A., 2003, Op soek na God buite die kerk, Lux Verbi, Wellington.

Nel, M., 2000, 'Persoonlike prediking', Praktiese Teologie in Suid-Afrika 15(2), 112 135.

Meuser, F., 1983, Luther the preacher, Augsburg, Minneapolis.

Müller, J., 2009, 'Mense, verhale en strukture: Armoede narratief benader', in G. Immink \& C. Vos (reds.), God in 'n kantelende wêreld, bl. 20-31, Protea Boekhuis, Pretoria.

Olyott, S., 1998, 'Pointed preaching' [Gefokusde prediking], Foundations 40, 42-43.

Osborne, G.R., 1995, 'Acts', in D.S. Briscoe, H. Robinson \& G.R. Osborne (eds.) The IVP New Testament Commentaries, pp. 17-400, Downers Grove, Leicester.

Osmer, R., 2010, Practical Theology: An introduction, Eerdmans, Grand Rapid.

Pieterse, H.J.C., 1990, Communicative preaching, University of South-Africa, Pretoria. Pieterse, H.J.C., 1991, Gemeente en prediking, NG Kerkboekhandel, Halfwayhouse, Pretoria.

Pieterse, H.J.C., 2001, Prediking in 'n konteks van armoede, UNISA Uitgewers, Pretoria.

Pieterse, H.J.C., 2008, 'Deelname van gemeentelede aan die prediking: 'n Herbesinning', Praktiese Teologie in Suid-Afrika 23(1), 139-154.

Pieterse, H.J.C., 2010, 'Die keuse van 'n model vir inhoudsanalise van preke oor armoede en aan armes as hoorders', In die Skriflig/In Luce Verbi 44(1), 121-136. $\mathrm{http}: / / \mathrm{dx}$.doi.org/10.4102/ids.v44i1.140

Plug, C., Meyer, W.F., Louw, D.A. \& Gouws, L.A., 1988, Psigologie-woordeboek, Lexicon, Johannesburg.

Ridderbos, H., 1985, Paul: An outline of his theology, Eerdmans, Grand Rapids.

Robinson, H.W., 2004, Expository preaching: Principles and practice, Baker House, Grand Rapids.

Smit, P.J. \& De J. Cronje, G.J., 1999, Management principles, Juta, Kenwyn.

Stark, C., 2005, Proeven van die preek: Een praktisch-theologisch onderzoek naar de preek als Woord van God, Boekencentrum, Zoetermeer.

Steinberg, S., 2011, An introduction to communication studies, Juta, Cape Town.

Stott, R.J.W., 1982, I believe in preaching, Hodder \& Stoughton, London.

Stott, R.J.W., 1999, New issues facing Christians today, Zondervan, Grand Rapids.

Troeger, T.H., 2007, 'Seeing visions and dreaming dreams: The imaginative power of preaching hope', in C. Vos, L.L. Hogan \& J.H. Cilliers (eds.), Preaching as a language of hope, pp. 73-80, Studia Homeletica, 6.

Tubbs, S. \& Moss, S., 2008, Human communication: Principles and contexts, McGrawHill, New York.

Van Leeuw, T \& Struijs, T., 2007, 'Preekbespreking of predikantsbespreking?', in M. Barnard, F. Borger, K. Bregman, R. Brouwer, G. van Ek, G. Immink, T. van Leeuw, T. Struijs, J. Muis, H. Schaap-Jonker, R. de Vries, I. de Zwart \& H. van der Meulen (reds.), Als een leerling leren preken, pp. 144-155, Boekencentrum, Zoetermeer.

Van der Meulen, H., 2008, 'Focus en functie, medidatie', in M. Barnard, F. Borger, K. Bregman, R. Brouwer, G. van Ek, G. Immink, T. van Leeuw, T. Struijs, J. Muis, H. Schaap-Jonker, R. de Vries, I. de Zwart \& H. van der Meulen (reds.), Als een leerling leren preken, pp. 80-90, Boekencentrum, Zoetermeer.

Vos, C.J.A., 1996, Die volheid daarvan (1): Homiletiek uit 'n hermeneutieskommunikatiewe hoek, RGN, Pretoria.

Weiten, W., 1992, Psychology: Themes and variations, Brooks \& Cole, New York.

Wilson, G.L., Hantz, A.M. \& Hanna, M.S., 1989, Interpersonal growth through communication, Brown, Dubuque.

Wood, S.E. \& Wood, E.G., 1999, The world psychology, Allyn \& Bacon, Boston.

Woolfolk, A., 2007, Educational psychology, Pearson, Boston. 